\title{
Pengaruh Kualitas Situs Web dan Karakteristik Konsumen terhadap Perilaku Pembelian Impulsif Konsumen pada Situs Web Tokopedia dengan Niat Pembelian sebagai Variabel Mediasi
}

\author{
Fidelia Utari* \\ Program Studi Manajemen Universitas Pelita Harapan \\ MH Thamrin Boulevard 1100, Karawaci, Tangerang, Banten, Indonesia \\ fideliautari@gmail.com \\ Cynthia Anna Wijayanti \\ Program Studi Manajemen Universitas Pelita Harapan \\ MH Thamrin Boulevard 1100, Karawaci, Tangerang, Banten, Indonesia \\ cynthia.wijayanti@uph.edu
}

Diterima: 09-02-2021

Disetujui: $16-06-2021$

Dipublikasi: 30-06-2021

\begin{abstract}
ABSTRAK
Penelitian ini bertujuan untuk meneliti pengaruh positif kualitas situs web dan karakteristik konsumen terhadap perilaku pembelian impulsif konsumen. Karakteristik konsumen yang diteliti dalam penelitian ini adalah excitement dan product knowledge, yang dimediasi oleh niat pembelian konsumen. Dalam beberapa tahun belakangan, jumlah pembelian daring telah meningkat, khususnya pada era pandemi yang mengharuskan masyarakat untuk tinggal di rumah. Tokopedia sebagai salah satu e-commerce terbesar di Indonesia, memiliki gross merchandise value tertinggi. Meskipun begitu, jumlah pengunjung situs web Shopee tercatat lebih tinggi. Karena itu, penelitian ini bertujuan menguji efek kualitas situs web dan karakteristik konsumen terhadap perilaku pembelian impulsif konsumen Tokopedia. Teknik pengambilan sampel yang digunakan adalah teknik nonprobability purposive dengan 191 responden yang telah mengisi kuesioner daring. Data yang diperoleh kemudian diolah dengan metode PLS-SEM. Hasil menunjukkan bahwa kualitas situs web tidak berpengaruh secara signifikan terhadap perilaku pembelian impulsif, namun excitement dan product knowledge memberikan pengaruh yang positif dan signifikan. Selain itu, niat pembelian tidak memiliki efek mediasi terhadap hubungan antara kedua karakteristik konsumen tersebut terhadap perilaku pembelian impulsif. Implikasi manajerial dari penelitian ini berupa saran kepada Tokopedia untuk lebih mempengaruhi perilaku pembelian impulsif konsumen agar Tokopedia dapat meningkatkan angka pembelanjaan secara online dan mengakomodasi kebutuhan masyarakat di era pandemi saat ini.
\end{abstract}

Kata Kunci:

Kualitas Situs Web; Karakteristik Konsumen; Niat Pembelian; Perilaku Pembelian; Impulsif Konsumen.

\begin{abstract}
This study aims to examine the positive effect of website quality and consumer characteristics on impulsive buying behaviour. The consumer characteristics examined in this study are excitement and product knowledge, which are mediated by buying intention. In recent years, the tendency to make online purchases through e-commerce has increased sharply, especially during the pandemic that requires people to stay at home. Tokopedia has the highest gross merchandise value in Indonesia. Even so, the number of Tokopedia website visitors has been in second place compared to Shopee. Therefore, a research about the effect of website quality and consumer characteristics on Tokopedias consumers impulsive buying behaviour is needed. The sampling technique used in this study is the non-probability purposive sampling. The sample was 191 respondents with a data collection method in the form of electronic questionnaires. Data was processed using the PLS-SEM method. The results showed that website quality do not significantly influence impulsive buying behaviour, while excitement and product knowledge have a positive and significant effect. In addition, buying intention has no mediating effect on the relationship between the two consumer characteristics and impulsive buying behaviour. The managerial
\end{abstract}


implication of this study would provide several recommendations for Tokopedia the effort of increasing impulsive buying behaviour to accommodate consumers needs in this pandemic era.

Keywords:

Website Quality; Consumer Characteristics; Purchase Intention; Purchasing Behavior; Consumer Impulsivity. 


\section{PENDAHULUAN}

Semakin banyak pengguna internet Indonesia kini aktif membeli dan menjual produk dan layanan secara online, baik dengan menggunakan laman resmi, media sosial, atau dengan aplikasi seluler (Freischlad, 2016), terlebih lagi di tengah era pandemi yang mengharuskan masyarakat untuk tetap tinggal di rumah. Pembelian secara online menjadi pilihan aman dalam menjalankan protokol kesehatan dan meminimalisir penyebaran Covid-19 dengan tetap mempermudah konsumen untuk berbelanja kebutuhannya.

Dari berbagai $e$-commerce yang ada di Indonesia, Tokopedia merupakan salah satu e-commerce terpopuler yang menunjukkan gross merchandise volume Tokopedia lebih tinggi dibandingkan Shopee dan Bukalapak (PT CLSA,2019) dimana gross merchandise volume atau biasa disebut GMV adalah nilai bersih produk yang dijual di pasar selama jangka waktu tertentu. Ini adalah indikator perkembangan bisnis yang digunakan untuk menilai pertumbuhan pasar pada wadah $e$ - commerce (Hayes, 2020)

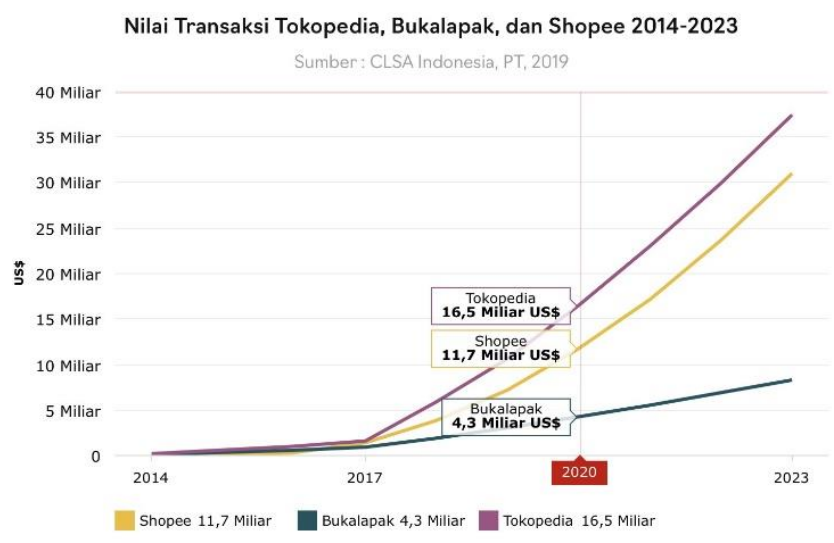

Gambar 1. Gross merchandise volume (GMV) Tokopedia, Bukalapak, dan Shopee 2014-2023 Sumber: PT CLSA Indonesia (2019)

Meski Tokopedia sudah dan diproyeksikan memiliki nilai GMV yang lebih tinggi dari Shopee dalam kurun waktu sepuluh tahun hingga 2023 (PT CLSA Indonesia, 2019), tetapi Shopee masih mencatatkan jumlah kunjungan laman bulanan tertinggi pada kuartal kedua tahun 2020 (Iprice Insights, 2020)

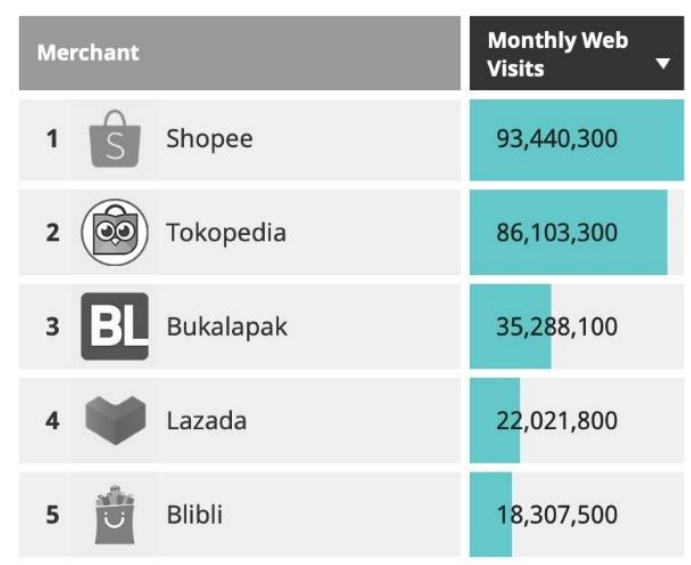

Gambar 2. 5 E-Commerce teratas di Indonesia (Q2 2020) Sumber: Iprice Insights (2020) 
Artinya, meski Tokopedia memiliki GMV lebih tinggi namun Shopee mengungguli Tokopedia dalam lalu lintas kunjungan ke lamannya. Inilah fenomena yang mendasari dilakukannya penelitian ini yang berfokus pada pengaruh kualitas situs web dan karakteristik konsumen (consumer excitement dan product knowledge) terhadap perilaku pembelian impulsif konsumen Tokopedia, yang dimediasi oleh niat pembelian konsumen terutama dalam kondisi pandemi saat ini. Variabel-variabel tersebut diteliti dengan dasar bahwa jika hipotesis yang dirumuskan dalam penelitian ini terbukti benar, maka Tokopedia dapat dan telah mendorong perilaku pembelian impulsif dari pengunjung situs webnya, sehingga dapat menghasilkan GMV yang lebih besar.

Berdasarkan latar belakang yang dikemukakan, maka pertanyaan penelitian yang dirumuskan dalam penelitian ini adalah sebagai berikut:

1. Apakah kualitas situs web secara positif mempengaruhi perilaku pembelian impulsif konsumen Tokopedia?

2. Apakah excitement secara positif mempengaruhi perilaku pembelian impulsif konsumen Tokopedia?

3. Apakah product knowledge secara positif mempengaruhi perilaku pembelian impulsif konsumen Tokopedia?

4. Apakah excitement secara positif mempengaruhi niat beli konsumen Tokopedia?

5. Apakah product knowledge secara positif mempengaruhi niat membeli konsumen Tokopedia?

6. Apakah niat beli konsumen Tokopedia secara positif mempengaruhi perilaku pembelian impulsif mereka?

Beberapa penelitian telah menunjukkan bahwa kualitas fitur situs web sangat mempengaruhi perilaku pembelian impulsif konsumen. Penelitian oleh Turkyilmaz et al. (2015) menunjukkan bahwa tiga aspek kualitas situs web, yaitu kemudahan penggunaan, hiburan, dan utilitas, memiliki pengaruh positif terhadap transaksi impulsif pengguna. Jika konsumen merasa bahwa situs web ritel online berkualitas baik, mereka dapat memiliki tingkat utilitas yang lebih tinggi untuk situs web tersebut dan cenderung mengembangkan keinginan untuk membeli (Van der Heijden, Verhagen \& Creemers, 2003). Sejalan dengan itu, Moez (2013) telah menunjukkan bahwa kualitas situs web, seperti navigasi, presentasi visual, dan pratinjau interaktif adalah tiga atribut utama bagi pengunjung situs web, yang secara bertahap mempengaruhi loyalitas dan juga niat pembelian mereka.

Selain kualitas situs web, faktor lain yang mempengaruhi perilaku pembelian impulsif adalah karakteristik konsumen. Karakteristik konsumen adalah ciri-ciri pribadi yang meningkatkan kecenderungan konsumen untuk menunjukkan perilaku tertentu (Youn \& Faber, 2000; Lin, 2006). Dalam penelitian-penelitian terdahulu tentang perilaku pembelian impulsif, beberapa penelitian telah mengartikan keinginan sebagai ciri pribadi individu. Individu bertanggung jawab atas transaksi impulsif yang bertentangan dengan pemikiran (Jalees, 2009). Chavosh, Halimi, dan Namdar (2011) juga 
menemukan adanya korelasi yang signifikan antara karakteristik konsumen dan dorongan untuk membeli.

Dua jenis karakteristik konsumen yang dibahas dalam penelitian ini adalah excitement dan product knowledge. Goyal dan Mittal (2007) sebagaimana dikutip dalam Ahmad, Ali, Malik, Humayun, dan Ahmad (2019) mengemukakan bahwa excitement saat melakukan aktivitas berbelanja merupakan ciri internal konsumen yang memotivasi individu untuk membelanjakan kebutuhan dan keinginannya. Sedangkan untuk product knowledge, konsumen cenderung membeli barang secara online karena mereka merasa memiliki detail produk yang memadai dari sumber daya daring (Akram, Hui, Khan, Hashim, \& Saduzai, 2017). Konsumen lebih memilih untuk membeli produk secara daring, karena memberikan pilihan kepada pembeli untuk melihat biaya dan detail produk, meningkatkan kenyamanan, dan secara efektif menemukan beberapa alternatif.

Selain itu, Hirschman (1980), dikutip oleh Irani (2000) mengusulkan bahwa pengalaman konsumen sebelumnya yang menguntungkan dengan suatu produk dapat "membutakan" mereka terhadap keunggulan praktis alternatif, dan dengan demikian berkontribusi pada pembelian impulsif. Terlepas dari seberapa kreatif produk tersebut, keakraban subjektif atau pengetahuan tentang produk yang ada mendorong keputusan pembelian dan perilaku konsumen. Berdasarkan hubungan antar variabel yang dijelaskan, 6 hipotesis dirumuskan dalam penelitian ini, sebagai berikut:

H1 : Kualitas situs web berpengaruh positif terhadap perilaku pembelian impulsif konsumen Tokopedia.

$\mathrm{H} 2$ : Excitement berpengaruh positif terhadap perilaku pembelian impulsif konsumen Tokopedia.

H3 : Product knowledge berpengaruh positif terhadap perilaku pembelian impulsif konsumen Tokopedia.

H4 : Excitement berpengaruh positif terhadap niat pembelian konsumen Tokopedia.

H5 : Product knowledge berpengaruh positif terhadap niat pembelian konsumen Tokopedia.

H6 : Niat pembelian berpengaruh positif terhadap perilaku pembelian impulsif konsumen Tokopedia.

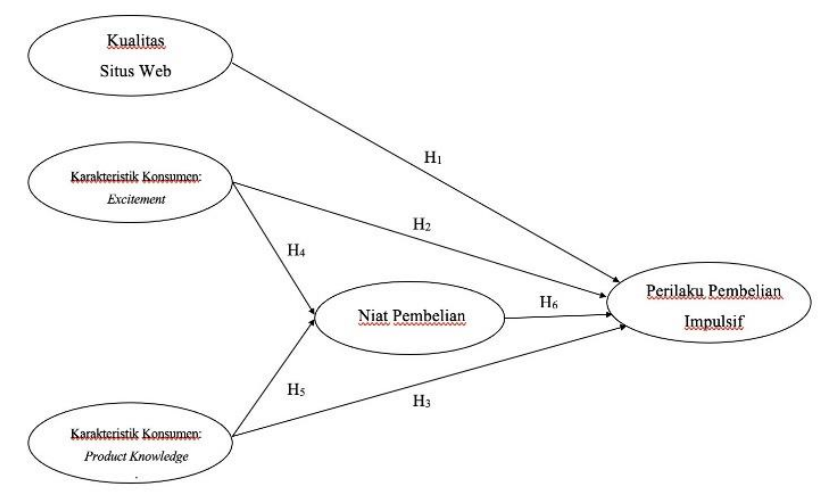

Gambar 3. Model Penelitian 


\section{METODE RISET}

Penelitian ini menggunakan metode kuantitatif yang bertujuan meneliti tentang pengaruh kualitas situs web dan karakteristik konsumen (consumer excitement dan product knowledge) terhadap perilaku pembelian impulsif pada situs web Tokopedia. Teknik pengambilan sampel yang digunakan dalam penelitian ini adalah teknik pengambilan sampling non-probabilitas (purposive sampling), dengan metode pengumpulan data berupa kuesioner elektronik.

Sampel penelitiannya adalah mereka yang memiliki pengalaman membeli produk minimal satu kali melalui situs web Tokopedia. Dari 219 responden yang mengisi kuesioner tersebut, 191 responden kemudian dipilih sebagai sampel dalam penelitian ini. 28 responden dieliminasi karena tidak memenuhi kriteria yang dibutuhkan untuk menjadi responden penelitian.

Data yang diperoleh kemudian diolah menggunakan metode Partial Least Square- Structural Equation Modeling dengan perangkat lunak SmartPLS. Dengan metode ini, pengolahan data dibagi menjadi dua bagian, yaitu outer model atau model pengukuran, dan inner model atau model struktural. Pengujian hipotesa kemudian dilaksanakan sebagai tahap terakhir dari analisis data statistika inferensial untuk membuktikan apakah hipotesis-hipotesis dalam penelitian ini didukung atau tidak

\section{HASIL PENELITIAN DAN PEMBAHASAN}

Pada model pengukuran atau outer model, uji validitas dan reliabilitas dilakukan menggunakan outer loading, average variance extracted (AVE), fornell-larcker criterion, dan juga composite reliability. Hasil pengujian outer loading menunjukkan bahwa 7 dari 28 indikator dinyatakan tidak valid, namun hanya indikator EV3 yang dieliminasi dengan tujuan untuk meningkatkan AVE dari kualitas situs web (X1). Setelah mengeliminasi EV3, AVE untuk tiap variabel dinyatakan valid dengan nilai lebih dari 0.5 .

Pengujian kemudian dilanjutkan dengan fornell-larcker criterion untuk menguji validitas diskriminan dan composite reliability untuk uji reliabilitas. Hasil dari kedua pengujian tersebut menunjukkan bahwa indikator untuk tiap variabel dinyatakan sebagai valid dan dapat diandalkan dengan nilai composite reliability lebih dari 0.7 .

Sedangkan pada model struktural, dilakukan uji multikolinearitas, analisa koefisien determinasi, serta perhitungan t-statistics. Pada uji multikolinearitas, variance inflation factor (VIF) menunjukkan nilai di bawah 5 untuk setiap variabel yang berarti tidak ada multikolinearitas yang terjadi. Analisa koefisien determinasi kemudian dilakukan dan hasil yang diperoleh 0.515 untuk niat pembelian dan 0.406 untuk perilaku pembelian impulsif. Kedua hasil tersebut dapat dikategorikan sebagai moderat.

Selanjutnya perhitungan t-statistics dilakukan dengan menggunakan batas 1.28 dan p-value sebesar 0.05. Hasil yang diperoleh menunjukkan bahwa H1 dan H6 ditolak karena memiliki p-value 
yang lebih tinggi dari 0.05. Pertama, H1 yang menggambarkan hubungan antara kualitas situs web dengan perilaku pembelian impulsif menunjukkan bahwa kualitas situs web tidak berpengaruh signifikan terhadap perilaku pembelian impulsive. Kemudian, H6 yang menggambarkan hubungan antara niat pembelian dengan perilaku pembelian impulsive menunjukkan bahwa niat beli tidak memiliki pengaruh mediasi terhadap hubungan antara kedua karakteristik konsumen tersebut dan perilaku pembelian impulsif.

Hubungan antara kualitas situs web dan perilaku pembelian impulsif yang tidak terbukti positif mendukung temuan Lo, Lin, dan Hsu (2016). Menurut Lo et al. (2016), dimensi kualitas situs web, seperti kemudahan penggunaan, kegunaan, dan nilai hiburan dianggap sebagai hygiene factor, yang merupakan salah satu dari 2 jenis faktor menurut two factor theory oleh Herzberg et al. (1966). Menurut teori tersebut, faktor dapat dikategorikan menjadi 2 yaitu motivational factor yang akan berpengaruh positif dan juga hygiene factor yang dapat memberikan pengaruh negatif. Karena itu, kualitas situs web yang tinggi itu sendiri mungkin tidak secara langsung memberi efek positif pada perilaku pembelian impulsif konsumen.

Adapun niat membeli tidak memberikan peran mediasi penuh pada hubungan antara karakteristik konsumen dan perilaku pembelian impulsif dikarenakan beberapa faktor. Misalnya, sekitar 15\% dari 191 responden dalam penelitian ini berada pada kategori usia di atas 40 tahun, yang dapat berakibat pada rendahnya perilaku pembelian impulsif. Hal ini didukung oleh Bellenger et al. (1978), sebagaimana dikutip dalam Bashar et al. (2013) yang mengamati bahwa konsumen yang berusia di bawah 35 tahun lebih rentan terhadap pembelian impulsif dibandingkan konsumen yang berusia di atas 35 tahun.

Kedua, penelitian ini dilakukan selama pandemi global Covid-19 yang mempengaruhi kondisi ekonomi sebagian besar negara, termasuk Indonesia. Laju pertumbuhan PDB global mengalami penurunan, yang membawa efek langsung pada perekonomian dan menurunkan ekspektasi pendapatan konsumen (Zhang, Leng \& Liu, 2020). Dengan berkurangnya pendapatan, walaupun konsumen memiliki niat pembelian yang besar, keputusan pembelian mereka dapat terhambat oleh sumber daya yang terbatas (Rana \& Tirthani, 2012; Ekeng, Lifu \& Asinya, 2012). Karena itu, temuan penelitian ini mungkin menunjukkan kecenderungan yang lebih rendah untuk perilaku pembelian impulsif meskipun konsumen memiliki niat beli yang kuat.

\section{KESIMPULAN DAN SARAN}

Berdasarkan pengolahan data, hasil yang didapatkan untuk setiap hipotesa adalah sebagai berikut:

H1 : Kualitas situs web berpengaruh positif terhadap perilaku pembelian impulsif konsumen Tokopedia tidak didukung

$\mathrm{H} 2$ : Excitement berpengaruh positif terhadap perilaku pembelian impulsif konsumen Tokopedia didukung 
H3 : Product knowledge berpengaruh positif terhadap perilaku pembelian impulsif konsumen Tokopedia didukung

$\mathrm{H} 4$ : Excitement berpengaruh positif terhadap niat pembelian konsumen Tokopedia didukung

H5 : Product knowledge berpengaruh positif terhadap niat pembelian konsumen Tokopedia didukung

H6 : Niat pembelian berpengaruh positif terhadap perilaku pembelian impulsif konsumen Tokopedia tidak didukung.

Sebagai kesimpulan, faktor utama yang mempengaruhi perilaku pembelian impulsif adalah consumer excitement dan product knowledge, sedangkan kualitas situs web berperan sebagai hygiene factor. Implikasi manajerial dari penelitian ini akan memberikan beberapa rekomendasi bagi Tokopedia pada berbagai faktor dalam upaya meningkatkan perilaku pembelian impulsif.

Pertama, penelitian ini menemukan bahwa kualitas situs web tidak berpengaruh positif terhadap perilaku pembelian impulsif konsumen. Berdasarkan statistik deskriptif kualitas situs web, hasil penelitian menunjukkan bahwa Tokopedia perlu meningkatkan daya tarik tata letak situs webnya. Lebih lanjut, penelitian ini menemukan bahwa consumer excitement dan product knowledge secara positif dan signifikan mempengaruhi perilaku pembelian impulsif. Namun, indikator excitement menunjukkan bahwa Tokopedia disarankan untuk menyediakan promosi, penawaran waktu terbatas, dan acara atau aktivitas khusus yang dapat menimbulkan excitement. Terakhir, statistik deskriptif product knowledge menunjukkan bahwa responden tidak sepenuhnya setuju bahwa informasi produk di situs web Tokopedia jelas. Oleh karena itu, pembuatan format standar informasi produk untuk penjual dapat membantu memastikan bahwa konsumen memiliki product knowledge yang lebih tinggi melalui laman Tokopedia.

Lebih lanjut, Tokopedia disarankan untuk menggunakan electronic word-of- mouth (eWOM) untuk meningkatkan pengetahuan pelanggan tentang produk. Salah satu cara untuk memuaskan eWOM konsumen adalah dengan mengaktifkan ulasan produk secara daring. Tokopedia harus mempertimbangkan untuk menggunakan ulasan konsumen ini sebagai alat pemasaran untuk bertindak sebagai pengaruh sosial dan merangsang perilaku pembelian konsumen yang impulsif.

Tokopedia dapat menyediakan format bagi pengguna untuk mengirimkan ulasan bermanfaat yang mencakup penilaian berbagai aspek produk. Untuk lebih mempromosikan perilaku pembelian impulsif, Tokopedia juga dapat mendorong konsumen untuk menulis lebih banyak ulasan foto atau video dengan memberi mereka reward. Ulasan yang berguna dapat meningkatkan pengalaman nyata dan waktu yang dihabiskan di situs web, yang kemudian akan meningkatkan perilaku pembelian impulsif konsumen (Zhang, Xu, Zhao \& Yu, 2018). Selain meningkatkan ketiga faktor tersebut, Tokopedia dapat mempertahankan jumlah serta jenis dan variasi produk yang dijual sehingga menarik lebih banyak konsumen untuk mengakses situs web Tokopedia, serta meningkatkan angka pembelanjaan secara online dan mengakomodasi kebutuhan masyarakat di era pandemi saat ini. 
Dalam melakukan penelitian ini, terdapat beberapa keterbatasan yang dialami dan saran untuk penelitian berikutnya. Pertama, dari 191 responden, sebagian besar (78\%) berasal dari generasi muda berusia antara 18 hingga 25 tahun. Mereka sebagian besar adalah mahasiswa dan karyawan awal karir, yang mungkin akan menimbulkan bias atas temuan yang diperoleh dalam penelitian ini. Oleh karena itu, penelitian ke depan harus memperluas penelitian pada beberapa generasi karena generasi yang lebih tua mungkin memiliki daya beli yang lebih tinggi dan cenderung lebih matang dalam siklus kehidupan keluarganya, sehingga memiliki perilaku yang berbeda.

Kedua, meskipun menggunakan kuesioner online, jawabannya sebagian besar berasal dari wilayah Jakarta. Oleh karena itu, penelitian ke depan harus berkonsentrasi pada kota-kota lain di Indonesia yang sering disebut-sebut sebagai kota dengan mayoritas pembeli online di Indonesia (Bachdar, 2016). Hasil penelitian tersebut akan menambah bukti komparatif yang dapat mem-validasi atau kemungkinan hasil yang tidak sejalan dengan temuan penelitian ini.

Ketiga, penelitian ini hanya meneliti dua variabel yaitu kualitas website dan karakteristik konsumen terhadap perilaku pembelian impulsif, baik secara langsung maupun melalui niat beli sebagai variabel mediasi, sedangkan terdapat variabel lain yang dapat mempengaruhi perilaku pembelian impulsif. Penelitian selanjutnya harus mengevaluasi variabel lain seperti kecenderungan membeli impulsif individu, ciri kepribadian, dan lain-lain yang berkorelasi dengan perilaku pembelian impulsif.

Keempat, karena subjek penelitian ini adalah konsumen Tokopedia, maka produk yang diteliti sangat beragam dan tidak terfokus pada kategori tertentu seperti fashion atau makanan dan minuman. Hal ini dapat menyebabkan bias pada hasil karena responden mungkin menjawab dengan mengacu pada beberapa produk di website. Penelitian di masa depan harus fokus pada sektor bisnis tertentu untuk menetapkan batasan pada produk yang diteliti dan mendapatkan hasil yang lebih spesifik dan dapat diterapkan pada industri tersebut.

Terakhir, perilaku pembelian impulsif dianggap sebagai strategi yang menguntungkan dan merupakan faktor positif dalam proses bisnis. Akibatnya, perspektif yang mungkin berbeda telah diabaikan dalam penelitian ini. Oleh karena itu, penelitian di masa mendatang direkomendasikan untuk memperluas pandangan tentang perilaku pembelian impulsif untuk mendapatkan pemahaman yang lebih dalam tentang bagaimana hal itu dipengaruhi dan mempengaruhi pasar. 


\section{DAFTAR PUSTAKA}

Ahmad, M. B., Ali, H. F., Malik, M. S., Humayun, A. A., dan Ahmad, S. (2019). Factors affecting impulsive buying behavior with mediating role of positive mood: An empirical study. European Online Journal of Natural and Social Sciences, 8(1), pp-17.

Akram, U., Hui, P., Khan, M. K., Hashim, M., dan Saduzai, S. K. (2017). Impulsive buying: a qualitative investigation of the phenomenon. In Proceedings of the Tenth International Conference on Management Science and Engineering Management (pp. 1383-1399). Springer, Singapore.

Bachdar, S. (2016). Lima kota Indonesia dengan jumlah pembelanja online terbesar. https://marketeers.com/lima-kota-indonesia-dengan-jumlah-pembelanja-online-terbesar/.

Barnes, S. dan Vidgen, R. (2000). WebQual: an exploration of website quality. ECIS 2000 proceedings, 74.

Bashar, A., Ahmad, I., dan Wasiq, M. (2013). A study of influence of demographic factors on consumer impulse buying behavior. Journal of Management Research, 13(3), 145-154.

Bošnjak, M., Bandl, A., dan Bratko, D. (2007). Measuring impulsive buying tendencies in Croatia: Towards a parsimonious measurement scale. In Marketing u društvu znanja i suvremenoj poslovnoj stvarnosti. Cromar.

Cahyorini, A., dan Rusfian, E. Z. (2012). The effect of packaging design on impulsive buying. Bisnis \& Birokrasi Journal, 18(1)

Chang, H. H., dan Chen, S. W. (2008). The impact of online store environment cues on purchase intention. Online information review.

Chavosh, A., Halimi, A. B., dan Namdar, J. (2011). The contribution of product and consumer characteristics of consumer impulse purchasing behavior in Singapore. Proceedings of International Conference on Social Science and Humanity (pp. 248-252). Singapore: IACSIT Press.

Choirul, A. dan Artanti, Y. (2019). Millennia's impulsive buying behavior: does positive emotion mediate?. Journal of Economics, Business, \& Accountancy Ventura, 22(2), 223-236.

Floh, A. dan Madlberger, M. (2013). The role of atmospheric cues in online impulse-buying behavior. Electronic Commerce Research and Applications, 12(6), 425-439. 
Utari, F. \& Wijayanti, C. A. (2021). Pengaruh Kualitas Situs Web dan Karakteristik Konsumen ....

Freischlad, N. (2016, August 26). Google: Indonesia will dominate Southeast Asian ecommerce. Tech in Asia. https://www.techinasia.com/google-temasek-ecommerce-data-indonesia.

Goyal, A., Maity, M., Thamizhvanan, A., dan Xavier, M. J. (2013). Determinants of customers' online purchase intention: an empirical study in India. Journal of Indian Business Research.

Harmancioglu, N.R., Finney, R.D.Z., dan Joseph, M. (2009), Impulse purchases of new products: An empirical analysis. Journal of Product and Brand Management, 18(1), 27-37.

Hayes, A. (2020). Gross merchandise value (GMV). https://www.investopedia.com/terms/g/grossmerchandise-value.asp.

Herzberg, F., Snyderman, B. B., dan Mausner, B. (1966). The Motivation to Work: 2d Ed. J. Wiley.

Iprice Insights. (2020). Top 5 e-commerce in Indoesia (Q2 2020). https://iprice.co.id/insights/mapofecommerce/en/

Irani, T. (2000). Prior Experience, Perceived Usefulness and the Web: Factors Influencing Agricultural Audiences' Adoption of Internet Communication Tools. Journal of Applied Communications, 4(2), 49-63.

Islam, H., Jebarajakirthy, C., dan Shankar, A. (2019). An experimental based investigation into the effects of website interactivity on customer behavior in on-line purchase context. Journal of Strategic Marketing, 1-24. https://doi.org/10.1080/0965254x.2019.1637923.

Jalees, T. (2009). An empirical analysis of impulsive buying behavior in Pakistan. Market Forces, 5(3).

Liu, Y., Li, H. and Hu, F. (2013). Website attributes in urging online impulse purchase: An empirical investigation on consumer perceptions. Decision Support Systems, 55(3), 829-837.

Lo, L. Y. S., Lin, S. W., dan Hsu, L. Y. (2016). Motivation for online impulse buying: A two-factor theory perspective. International Journal of Information Management, 36(5), 759-772.

Manu, A. (2016). Value creation and the Internet of things: How the behavior economy will shape the 4th industrial revolution. New York: Routledge.

Moez, L. (2013). Antecedents and effect of commitment on the impulse buying by internet. Journal.of Internet Banking and Commerce, 18(1), 1-22. 
Parboteeah, D. V., Valacich, J. S., dan Wells, J. D. (2009). The influence of website characteristics on a consumer's urge to buy impulsively. Information Systems Research, 20(1), 60-78.

Pavlou, P. A. (2003). Consumer acceptance of electronic commerce: Integrating trust and risk with the technology acceptance model. International journal of electronic commerce, 7(3), 101-134.

PT CLSA Indonesia (2019). Nilai Transaksi Tokopedia, Bukalapak, dan Shopee 2014-2023.

Rana, S., dan Tirthani, J. (2012). Effect of education, income and gender on impulsive buying among Indian consumer an empirical study of readymade garment customers. Management, 1(12).

Sihombing, E. S., Budi, I., dan Munajat, Q. (2020). Factors affecting the urge of impulsive buying on social commerce Instagram. International Journal of Internet Marketing and Advertising, 14(3), 236-257.

Silviana, C. (2019, October 17). Ecommerce, ride-hailing fastest-growing sectors in SEA, Indonesia. Tech in Asia. https://www.techinasia.com/ecommerce-ride-hailing-fastest-growing-sectors-seaindonesia.

Turkyilmaz, C. A., Erdem, S., dan Uslu, A. (2015). The effects of personality traits and website quality on online impulse buying. Procedia-Social and Behavioral Sciences, 175, 98-105.

Van der Heijden, H., Verhagen, T., dan Creemers, M. (2003). Understanding online purchase intentions: contributions from technology and trust perspectives. European Journal of Information Systems, $12(1), 41-48$.

Wells, J.D., Parboteeah, V. and Valacich, J.S. (2011). Online impulse buying: Understanding the interplay between consumer impulsiveness and website quality. Journal of The Association for Information Systems, 12(1), 32-56.

Youn, S., dan Faber, R.J. (2000). Impulse buying: Its relation to personality traits and cues. Advances in Consumer Research, 27, 179-186.

Zhang, K. Z., Xu, H., Zhao, S., dan Yu, Y. (2018). Online reviews and impulse buying behavior: the role of browsing and impulsiveness. Internet Research.

Zhang, W., Leng, X., dan Liu, S. (2020). Research on mobile impulse purchase intention in the perspective of system users during COVID-19. Personal and Ubiquitous Computing, 1-9. 


\section{LAMPIRAN}

Tabel 1. Definisi Operasional \& Konseptual

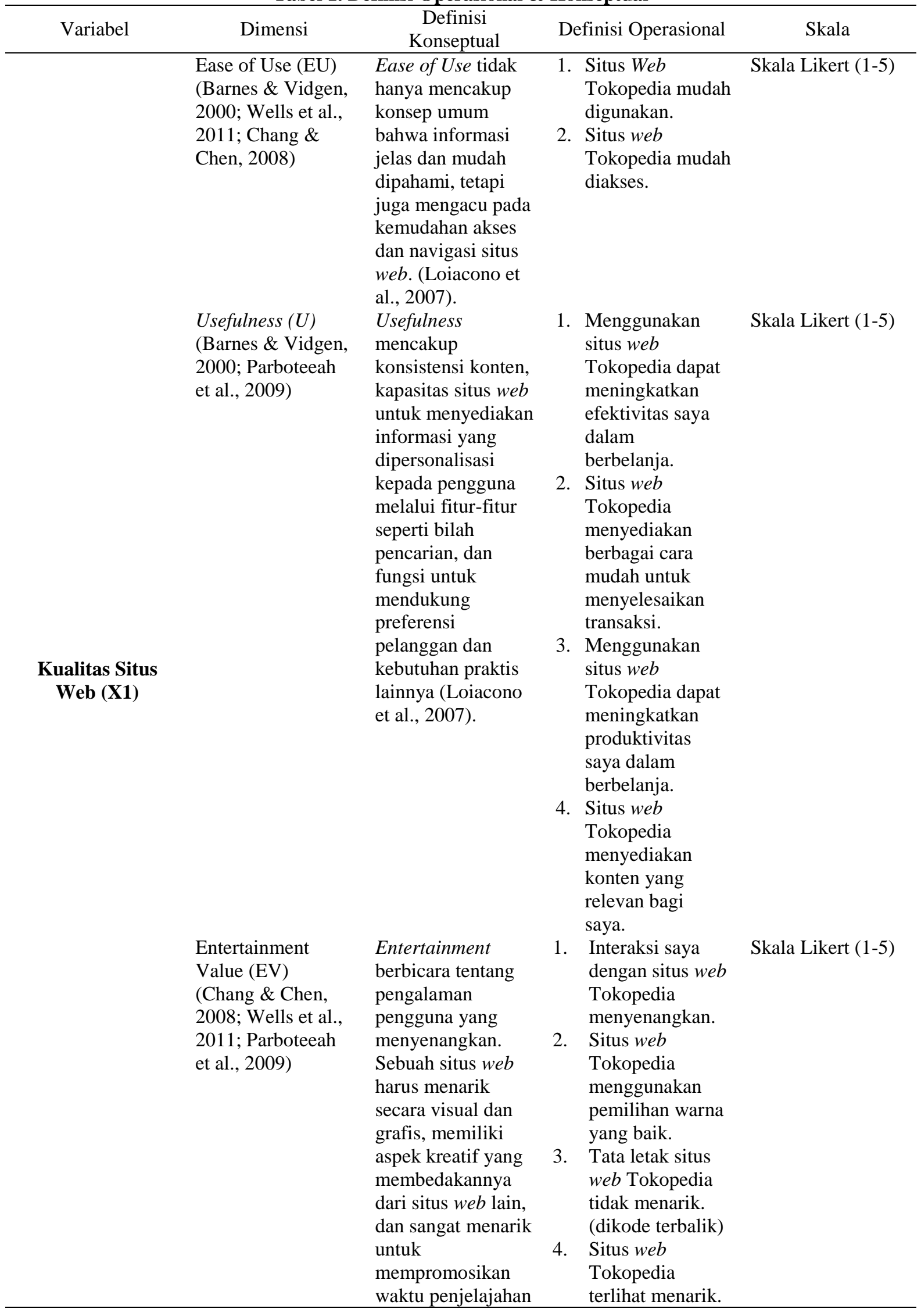




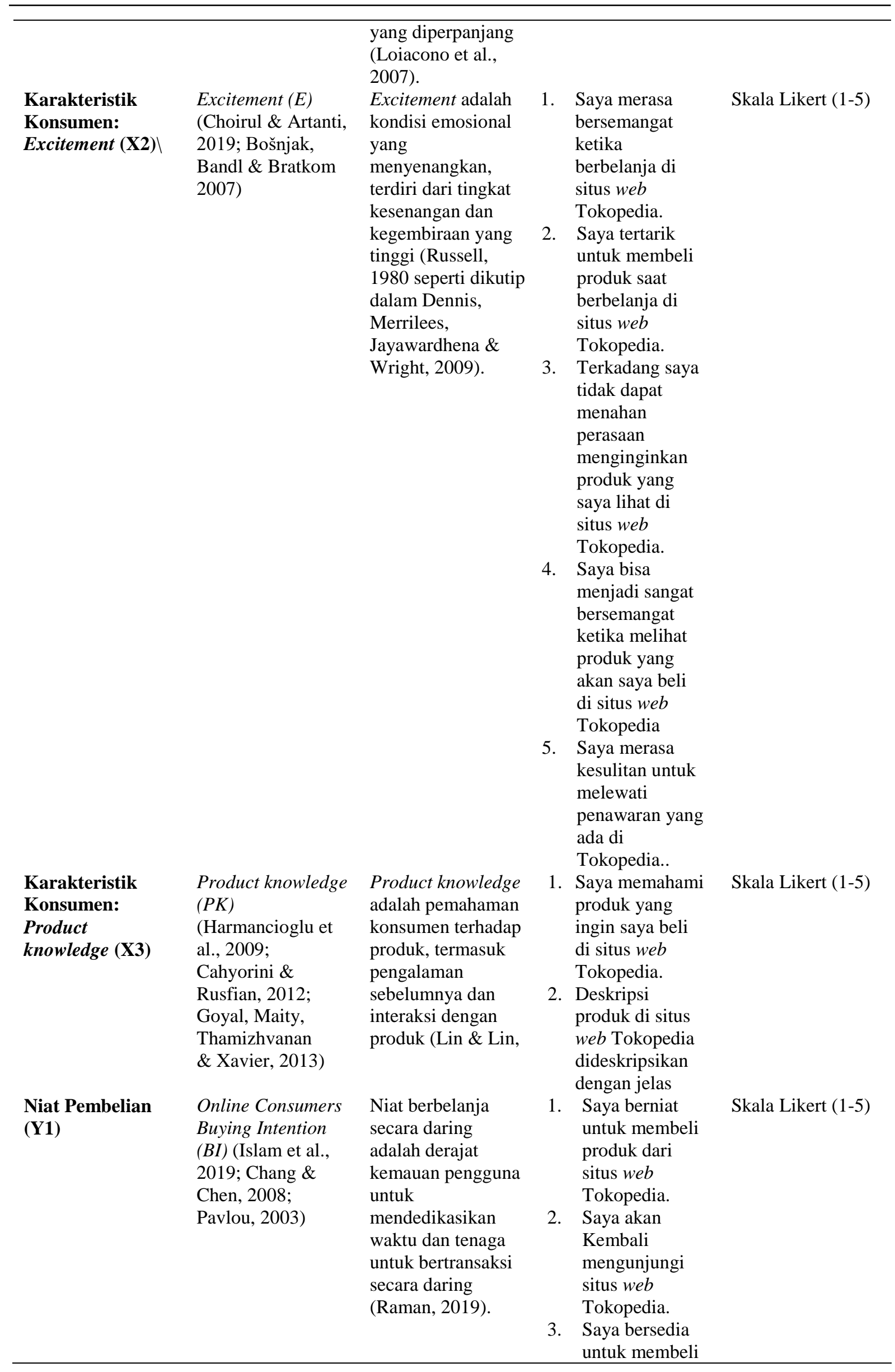


Perilaku

Pembelian Impulsif (Y2)
Online Impulsive

Buying Behaviour

(IB) (Floh \&

Madlberger, 2013;

Liu et al., 2013;

Choirul \& Artanti,

2019, Sihombing,

Budi \& Munajat, 2020)

produk dari

situs web

Tokopedia.

4. Saya sangat berminat untuk membeli produk dari situs web

Tokopedia.

Perilaku pembelian impulsif adalah transaksi spontan dan tidak terduga tanpa rencana prabelanja baik untuk membeli produk tertentu atau untuk melaksanakan tugas pembelian tertentu (Beatty \& Ferrell, 1998, seperti dikutip oleh Sharma, Joshi \& Kumar, 2015).
1. Ketika saya berbelanja di situs web Tokopedia, saya membeli produk yang tidak saya rencanakan sebelumnya.

2. Ketika saya berbelanja di situs web Tokopedia, saya sering membeli produk tanpa memikirkan konsekuensinya.

3. Ketika saya berbelanja di situs web Tokopedia dan sangat tertarik pada suatu produk, saya akan membeli produk tersebut.

4. Ketika saya berbelanja di situs web Tokopedia, berbelanja secara spontan sangat menyenangkan.

5. Saya dapat membeli produk di situs web Tokopedia tanpa perencanaan.

6. Pernyataan "Beli sekarang, berpikir kemudian" mendeskripsikan saya.

7. Saya membeli produk di situs web Tokopedia berdasarkan pada suasana hati saya pada saat itu.
Skala Likert (1-5) 
Tabel 2. Average Variance Extracted (AVE)

\begin{tabular}{ccc}
\hline Variabel & AVE & Kategori $(>0.5)$ \\
\hline X1 & 0.467 & Tidak Valid \\
X2 & 0.578 & Valid \\
X3 & 0.714 & Valid \\
Y1 & 0.769 & Valid \\
Y2 & 0.636 & Valid \\
\hline \multicolumn{3}{r}{}
\end{tabular}

Tabel 3. Outer Loading

\begin{tabular}{|c|c|c|c|}
\hline Variabel & Kode Indikator & Outer Loading & Kategori $(>0.7)$ \\
\hline \multirow{10}{*}{$\mathrm{X} 1$} & EU1 & 0.615 & Tidak Valid \\
\hline & EU2 & 0.666 & Tidak Valid \\
\hline & U1 & 0.811 & Valid \\
\hline & U2 & 0.701 & Valid \\
\hline & U3 & 0.747 & Valid \\
\hline & U4 & 0.697 & Invalid \\
\hline & EV1 & 0.820 & Valid \\
\hline & EV2 & 0.685 & Tidak Valid \\
\hline & EV3 & 0.122 & Tidak Valid \\
\hline & EV4 & 0.705 & Valid \\
\hline \multirow{5}{*}{$\mathrm{X} 2$} & E1 & 0.809 & Valid \\
\hline & E2 & 0.833 & Valid \\
\hline & E3 & 0.825 & Valid \\
\hline & E4 & 0.842 & Valid \\
\hline & E5 & 0.388 & Tidak Valid \\
\hline \multirow{3}{*}{$\mathrm{X} 3$} & PK1 & 0.840 & Valid \\
\hline & PK2 & 0.850 & Valid \\
\hline & BI1 & 0.850 & Valid \\
\hline \multirow{3}{*}{ Y1 } & BI2 & 0.866 & Valid \\
\hline & $\mathrm{BI} 3$ & 0.895 & Valid \\
\hline & BI4 & 0.896 & Valid \\
\hline \multirow{7}{*}{ Y2 } & IB1 & 0.849 & Valid \\
\hline & IB2 & 0.785 & Valid \\
\hline & IB3 & 0.582 & Tidak Valid \\
\hline & IB4 & 0.880 & Valid \\
\hline & IB5 & 0.876 & Valid \\
\hline & IB6 & 0.781 & Valid \\
\hline & IB7 & 0.792 & Valid \\
\hline
\end{tabular}

Sumber: Analisis Data SmartPLS

Tabel 4. Average Variance Extracted (AVE) Revised

\begin{tabular}{ccc}
\hline Variable & AVE & Category $(>\mathbf{0 . 5})$ \\
\hline WQ & 0.522 & Valid \\
E & 0.578 & Valid \\
PK & 0.714 & Valid \\
BI & 0.769 & Valid \\
IB & 0.636 & Valid \\
\hline
\end{tabular}

Sumber: Analisis Data SmartPLS 
Utari, F. \& Wijayanti, C. A. (2021). Pengaruh Kualitas Situs Web dan Karakteristik Konsumen ....

Table 5. Fornell-Larcker Criterion

\begin{tabular}{lccccc}
\hline \multicolumn{7}{c}{ X1 } & X2 & $\mathbf{X 3}$ & Y1 & Y2 \\
\hline X1 & 0.723 & & & & \\
$\mathbf{X 2}$ & 0.713 & 0.760 & & & \\
$\mathbf{X 3}$ & 0.580 & 0.535 & 0.845 & & \\
Y1 & 0.675 & 0.652 & 0.603 & 0.877 & \\
Y2 & 0.383 & 0.614 & 0.410 & 0.354 & 0.798 \\
\hline \multicolumn{6}{c}{ Sumber: Analisis Data SmartPLS }
\end{tabular}

Table 6. Reliability

\begin{tabular}{lcl}
\hline Variabel & Composite Reliability & Kategori $>\mathbf{0 . 7}$ \\
\hline X1 & 0.907 & Reliable \\
X2 & 0.866 & Reliable \\
X3 & 0.833 & Reliable \\
Y1 & 0.930 & Reliable \\
Y2 & 0.923 & Reliable \\
\hline & Sumber: Analisis Data SmartPLS
\end{tabular}

Tabel 7. Variance Inflation Factor (VIF)

\begin{tabular}{lcc}
\hline & Y1 & Y2 \\
\hline $\mathbf{X 1}$ & & 2.522 \\
$\mathbf{X 2}$ & 1.402 & 2.309 \\
$\mathbf{X 3}$ & 1.402 & 1.740 \\
Y1 & & 2.272 \\
Y2 & \\
\hline \multicolumn{2}{c}{ Sumber: Analisis Data SmartPLS }
\end{tabular}

Tabel 8. Coefficient of Determination $\left(\boldsymbol{R}^{2}\right)$

$\frac{\frac{\text { Rsquare }}{\text { Y1 }}}{\text { Sumber: Analisis Data SmartPLS }}$

Tabel 9. Koefisien Jalur

\begin{tabular}{|c|c|c|c|}
\hline & Original Sample & $T$-Statistics & P-Value \\
\hline X1 -> Y2 & -0.140 & 1.552 & 0.060 \\
\hline X2 -> Y1 & 0.685 & 6.716 & 0.000 \\
\hline $\mathrm{X} 2$-> Y2 & 0.193 & 8.102 & 0.000 \\
\hline X3 -> Y1 & 0.462 & 4.693 & 0.000 \\
\hline X3 -> Y2 & 0.355 & 2.588 & 0.005 \\
\hline $\mathbf{Y} 1$-> Y2 & -0.115 & 1.403 & 0.080 \\
\hline
\end{tabular}

Sumber: Analisis Data SmartPLS

Tabel 11. Specific Indirect Effects

\begin{tabular}{|c|c|c|c|}
\hline & Original Sample & T-Statistics & P-Value \\
\hline $\bar{X} 2$-> Y1 -> Y2 & -0.053 & 1.350 & 0.089 \\
\hline $\mathrm{X} 3$-> Y1 -> Y2 & -0.041 & 1.286 & 0.099 \\
\hline
\end{tabular}


Tabel 12. Total Effects

\begin{tabular}{lccc}
\hline & Original Sample & T-Statistics & P-Value \\
\hline X1 -> Y2 & -0.140 & 1.552 & 0.060 \\
X2 -> Y2 & 0.632 & 7.781 & 0.000 \\
X3 -> Y2 & 0.153 & 2.156 & 0.016 \\
X2 -> Y1 & 0.462 & 6.716 & 0.000 \\
X3 -> Y1 & 0.355 & 4.693 & 0.000 \\
Y1 -> Y2 & -0.115 & 1.403 & 0.080 \\
\hline
\end{tabular}

Sumber: Analisis Data SmartPLS 